\title{
Predictor of Left Atrial Spontaneous Echocardiographic Contrast in Rheumatic Mitral Stenosis Patients
}

\author{
Komaria, Abdul Halim R, Ali Nafiah Nst, Harris Hasan
}

Department of Cardiology and Vascular Medicine, Faculty of Medicine Universitas Sumatera Utara, Haji Adam Malik General Hospital, Medan, Indonesia
Background: Previously conducted researches showed that presence of SEC in the left atrium can constitute a risk factor for thrombus formation. Some previous studies have also reported that in addition to atrial fibrillation and blood stasis in the left atrium, the pathophysiology of left atrial thrombus and SEC occurring in patients with rheumatic mitral stenosis exhibits some other mechanisms, such as autoimmunity, inflammation and increased thrombotic activity.

Methods: Cross sectional study was conducted between July 2015 to July 2017 in patient who admitted to Haji Adam Malik Hospital due to rheumatic mitral stenosis. They were divided into two groups according to presence of left atrial SEC.

Result: From I04 patients, 52 (mean age $40 \pm$ II years; 7I,2\% women) were in the left atrial SEC-negative group and 52 patients (mean age $40 \pm 10$ years; 73, $1 \%$ women) were in the left atrial SEC-positive group. There were no significant differences in

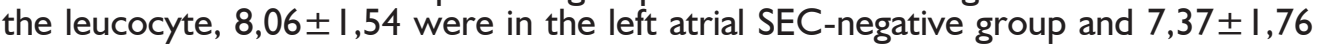
were in the left atrial SEC-positive group. In multivariate analysis, atrial fibrillation (OR $=5 \mathrm{I}, 3 \mathrm{II}, 95 \% \mathrm{Cl} 3,723-707,100, p=0,003)$ neutrophil/lymphocyte ratio $(\mathrm{OR}=$ $2 \mathrm{I}, 64 \mathrm{I}, 95 \% \mathrm{Cl} 5, \mathrm{I} 74-90,528, p<0,00 \mathrm{I})$, mitral valve area $(\mathrm{OR}=14,423,95 \% \mathrm{Cl}$ I,665 - I24,908, $p=0,0$ I5), and RDW (OR = 5,743,95\% Cl I,349-24,445, $p=$ 0,0 I8), These study show that neutrophil/lymphocyte ratio with cut off point of $>3,2$ had sensitivity, spesificity, positive predictive value, and negative predictive value to predict left atrial SEC is the same $81 \%$, respectively.

Conclusion: Atrial fibrillation, neutrophil/lymphocyte ratio, RDW and mitral valve area can predict left atrial spontaneous echocardiographic contrast in rheumatic mitral stenosis patients.

(Indonesian J Cardiol. 2017;38:168-78)

Keyword: Spontaneous echo contrast (SEC), atrial fibrillation, neutrophil/lymphocyte ratio, red cell distribution width (RDW) and mitral valve area. 


\title{
Prediktor Kejadian Spontaneous Echocardiographic Contrast di Atrium Kiri pada Penderita Stenosis Mitral Rematik
}

\author{
Komaria, Abdul Halim R, Ali Nafiah Nst, Harris Hasan
}

Latar Belakang: Penelitian sebelumnya menunjukkan adanya SEC di atrium kiri menjadi faktor risiko untuk pembentukan trombus. Pada pasien stenosis mitral rematik, risiko trombosis dan perkembangan SEC di atrium kiri tinggi. Beberapa penelitian sebelumnya melaporkan bahwa patofisiologi trombus dan SEC di atrium kiri selain fibrilasi atrium dan stasis aliran darah di atrium kiri juga adanya beberapa mekanisme lain seperti respon imun, inflamasi dan peningkatan aktifitas trombotik.

Metode: Ini adalah penelitian observasional yang bersifat cross sectional, dilakukan dari Juli 2015 sampai Juli 2017 terhadap pasien stenosis mitral rematik yang datang ke rumah sakit Haji Adam Malik. Pasien dibagi 2 kelompok berdasarkan kehadiran SEC di atrium kiri menurut hasil pemeriksaan ekokardiografi.

Hasil: Didapatkan 104 pasien, dimana 52 pasien (usia rata-rata $40 \pm 11$ tahun, $71 \%$ wanita) merupakan kelompok tanpa SEC, dan 52 pasien (usia rata-rata $40 \pm 10$ tahun, 73\% wanita) merupakan kelompok dengan SEC. Tidak ada perbedaan bermakna pada lekosit, dimana kelompok tanpa SEC $(8,06 \pm 1,54)$ dan kelompok dengan SEC $(7,37 \pm 1,76)$. Dari analisis multivariat regresi logistik, didapatkan fibrilasi atrium $(\mathrm{OR}=$ 51,311, nilai IK 95\% antara 3,723 - 707,100, $p=0,003)$ rasio netrofil/limfosit (OR = 21,641, nilai IK 95\% antara 5,174 - 90,528, nilai $p<$ $0,001)$, area katup mitral $(\mathrm{OR}=14,423$, nilai IK 95\% antara 1,665 - 124,908, nilai $p=0,015)$, dan RDW (OR $=5,743$, nilai IK 95\% antara $1,349-24,445$, nilai $p=0,018)$, merupakan prediktor independen untuk terjadinya SEC. Titik potong untuk nilai rasio N/L > 3,2 memiliki angka sensitivitas, sensitifitas, nilai prediktif positif dan nilai prediktif negatif yang sama yaitu masing-masing $81 \%$ untuk memprediksi kejadian SEC di atrium kiri pada pasien stenosis mitral rematik.

Kesimpulan: Fibrilasi atrium, rasio netrofil/limfosit, RDW dan area katup mitral dapat menjadi prediktor SEC di atrium kiri pada pasien stenosis mitral rematik.

(Indonesian J Cardiol. 2017;38:168-78)

Kata kunci: Spontaneous echocardiographic contrast (SEC), fibrilasi atrium, rasio neutrofil/limfosit (rasio N/L), red cell distribution width (RDW) dan area katup mitral.

Departemen Kardiologi dan Kedokteran Vaskular, Fakultas Kedokteran Universitas Sumatera Utara, Rumah Sakit Umum Haji Adam Malik, Medan, Indonesia.

\section{Correspondence:}

dr. Komaria, Department of Cardiology and Vascular Medicine, Faculty of Medicine Universitas Sumatera Utara, Haji Adam Malik General Hospital, Medan, Indonesia. Tel.: +628I36774485I. E-mail: ko2m77@yahoo.com

\section{Pendahuluan}

Stenosis mitral saat ini masih merupakan kelainan katup yang cukup sering ditemui terutama di negara berkembang termasuk Indonesia yang sebagian besar akibat demam rematik, diawali dengan radang tenggorokan yang disebabkan oleh kuman 
streptokokkus dan selanjutnya akan menimbulkan respon inflamasi sistemik termasuk di daerah katup. Respon inflamasi kemudian menimbulkan kerusakan katup hingga terjadi stenosis katup mitral. Beberapa penelitian sebelumnya menunjukkan bahwa proses inflamasi kronik berlangsung terus menerus pada penyakit katup mitral rematik. ${ }^{1}$

Stenosis mitral merupakan kondisi obstruksi aliran darah ke ventrikel kiri karena katup mitral tidak terbuka secara sempurna pada fase diastolik. ${ }^{2}$ Gangguan ini menyebabkan stasis darah dan peningkatan tekanan di ruang atrium kiri. Kondisi ini bersama dengan inflamasi akan menyebabkan pelebaran atrium kiri, fibrosis dinding atrium dan disorganisasi bundel otot atrium. Perubahan yang terjadi akan memicu terjadinya fibrilasi atrium. Pada fase kronik, kondisi tersebut akan meningkatkan risiko pembentukan trombus dan emboli sistemik pada pasien stenosis mitral rematik. Angka kejadian SEC pada stenosis mitral rematik bervariasi dari $21 \%-67 \% .{ }^{3,4}$

Pembentukan trombus sendiri sebenarnya belum jelas mekanismenya namun dalam beberapa sumber sering dikaitkan dengan adanya spontaneous echocardiographic contrast (SEC). Menurut penelitian Shintaro, insidensi trombus di atrium kiri pada pasien dengan SEC sekitar 60\% dan tanpa SEC hanya 9\%. ${ }^{5}$ Spontaneous echocardiographic contrast adalah suatu gambaran seperti asap dengan gerakan berputar-putar yang ditemukan pada saat pemeriksaan ekokardiografi. Mekanisme pembentukan SEC sendiri masih tidak jelas. Beberapa penelitian sebelumnya melaporkan bahwa patofisiologi trombus dan SEC di atrium kiri selain dari fibrilasi atrium dan stasis aliran darah di atrium kiri juga disertai adanya beberapa mekanisme lain seperti autoimun, inflamasi, peningkatan aktifitas trombotik, hemoreologi seperti peningkatan hematokrit dan fibrinogen, serta gangguan agregasi platelet dan aktivasi sel darah putih. ${ }^{6}$

Neutrofil dan limfosit adalah jenis sel darah putih yang akhir-akhir ini banyak diteliti sebagai penanda baru untuk trombosis dan inflamasi yang ditemukan berhubungan dengan derajat keparahan dan prognosis dari beberapa penyakit kardiovaskuler., Rasio neutrofil/limfosit (rasio N/L) menunjukkan indikator status inflamasi yang merupakan gabungan dari neutrofil dan limfosit, dimana penyebab utama dari peningkatan rasio N/L adalah kemungkinan karena peningkatan apoptosis limfosit yang dipicu oleh peningkatan status inflamasi pada pasien stenosis mitral rematik. Peningkatan rasio N/L berhubungan secara bermakna dengan SEC di atrium kiri pada pasien stenosis mitral rematik dalam beberapa penelitian epidemiologi..$^{9,10}$

Oleh karena itu penelitian ini bertujuan untuk mengetahui hubungan fibrilasi atrium, rasio neutrofil/ limfosit dan area katup mitral dengan spontaneous echocardiographic contrast dan apakah parameter tersebut bisa memprediksi kejadian SEC di atrium kiri pada penderita stenosis mitral rematik.

\section{Metode Penelitian}

Penelitian ini merupakan penelitian observasional yang bersifat cross sectional dengan populasi penelitian adalah semua pasien dengan stenosis mitral rematik yang menjalani pemeriksaan ekokardiografi di divisi noninvasif Departemen Kardiologi Rumah Sakit Umum Haji Adam Malik Medan. Kriteria inklusi adalah penderita stenosis mitral rematik yang menjalani pemeriksaan ekokardiografi mulai Juli 2015 - Juli 2017 dan kriteria eksklusi adalah trombus di atrium kiri, keganasan, penyakit inflamasi, pemakaian obat kortikosteroid dan NSAID, penyakit jaringan konektif, penyakit tiroid, kelainan hematologi, dan jarak antara pengambilan darah untuk pemeriksaaan laboratorium dan pemeriksaan ekokardiografi tidak lebih dari 2 hari.

Populasi penelitian dibagi dalam dua kelompok berdasarkan kehadiran SEC di atrium kiri. Kelompok pertama adalah populasi penderita stenosis mitral rematik dengan tanpa SEC di atrium kiri dan kelompok kedua adalah populasi penderita stenosis mitral rematik dengan SEC di atrium kiri. Pengumpulan sampel menggunakan metode kuota (consecutive) dengan jumlah sampel minimal berdasarkan rumus perhitungan sampel adalah 49 penderita untuk masing-masing kelompok.

\section{Prosedur Penelitian}

Data dasar mengenai identitas, riwayat obat dan penyakit sebelumnya didapatkan dari buku rekam medis. Fibrilasi atrium ditentukan dari rekaman elektrokardiografi. Gambaran SEC didapat dari rekaman ekokardiografi. Definisi SEC disini adalah suatu gambaran seperti asap dengan gerakan berputarputar di ruang utama atrium kiri yang ditemukan pada pemeriksaan ekokardiografi transtorakal. Penilaian SEC 
dilakukan oleh satu orang konsultan ekokardiografi yang terlebih dahulu dilakukan uji Kappa intraobserver untuk mencari kesesuaian interpretasi. Dari uji Kappa yang dilakukan, diperoleh nilai sebesar 0,885 dengan $p<0,001$, artinya terdapat kesesuaian yang sangat kuat antara pengamatan pertama dan pengamatan kedua.

Pemeriksaan menggunakan alat ekokardiografi transtorakal (TTE) dengan spesifikasi alat yang dipakai 2 jenis yaitu GE Vivid S6 dengan sector heart probe frekuensi 3,2MHz dan Medison Accuvix 10 dengan sector heart probe frekuensi $3.50 \mathrm{MHz}$. Area katup mitral diukur dengan menggunakan metode planimetri. Jet dari regurgitasi trikuspid diidentifikasi lalu diukur tekanan gradiennya sebanyak $\geq 5$ (untuk irama sinus) atau $\geq 8$ (untuk irama fibrilasi atrium). Bila gradien ini ditambahkan dengan asumsi tekanan atrium kanan $(10 \mathrm{mmHg})$ maka akan didapatkan nilai tekanan arteri pulmonal sistolik.

Sampel darah penderita diambil dari vena kubiti sesegera mungkin setelah dilakukan ekokardiografi untuk dianalisis di laboratorium. Darah dimasukkan ke dalam tabung yang berisi ethylenediaminetetraacetic acid (EDTA), kemudian dilakukan pemeriksaan darah rutin dengan menggunakan Sysmex Xt 4000i dan Sysmex Xt 2000i secara auto-analisis selama 5 menit.

\section{Analisis Data}

Data hasil penelitian dianalisis secara statistik dengan bantuan program SPSS versi 17. Variabel kontinu dilaporkan dalam bentuk mean \pm standar deviasi atau nilai median. Variabel kategorik dilaporkan dalam bentuk frekuensi dan persentase. Sebelum dilakukan uji komparatif untuk variabel kontinu, dilakukan terlebih dahulu uji normalitas distribusi data dengan menggunakan uji Kolmogorov-Smirnov. Kemudian dilakukan uji $\mathrm{T}$ atau uji Mann-Whitney untuk membandingkan data-data kontinu antara dua kelompok tidak berpasangan.

Variabel-variabel yang akan dimasukkan ke dalam regresi logistik adalah variabel yang pada analisis bivariat mempunyai nilai $p \leq 0,1$, dimana nilai ini dianggap sebagai penanda risiko yang potensial untuk terjadinya SEC. Analisis multivariat regresi logistik menggunakan cara eliminasi backward dengan signifikansi nilai $p<$ 0,05 dan interval kepercayaan 95\%.

Sebelum pengolahan data, terlebih dahulu dilakukan uji Kappa untuk mencari kesesuaian interpretasi. Penilaian SEC di atrium kiri dilakukan oleh dua orang konsultan ekokardiografi. Dari uji Kappa intraobserver diperoleh nilai sebesar 0,885 dengan $\mathrm{p}<0,001$ dan uji Kappa interobserver diperoleh nilai sebesar 0,923 dengan $p<0,001$, artinya keduanya terdapat kesesuaian yang sangat kuat antara pengamatan pertama dan pengamatan kedua.

\section{Hasil Penelitian}

\section{Karakteristik Subyek Penelitian}

Dari 104 subyek penelitian, didapatkan 52 orang tanpa SEC di atrium kiri dan 52 orang dengan SEC di atrium kiri. Umur rata-rata dan jenis kelamin dari subyek penelitian hampir sama antara dua kelompok, dengan nilai $p$ masing-masing adalah $p=0,962$ dan $p=0,827$. Umur rata-rata subyek penelitian tanpa SEC di atrium kiri adalah 40,25 $\pm 10,63$ tahun sedangkan subyek dengan SEC di atrium kiri adalah 40,15 $\pm 9,72$ tahun. Jenis kelamin perempuan terdiri dari 37 orang $(71,2 \%)$ tanpa SEC di atrium kiri dan 38 orang $(73,1 \%)$ dengan SEC di atrium kiri, sedangkan jenis kelamin lakilaki 15 orang $(28,8 \%)$ tanpa SEC di atrium kiri dan 14 orang $(26,9 \%)$ dengan SEC di atrium kiri. Dari karakteristik data dasar subyek penelitian, didapatkan jenis kelamin perempuan lebih banyak menderita penyakit stenosis mitral dibanding laki-laki. Sedangkan dari segi umur terlihat bahwa tidak ada perbedaan usia antara kelompok pasien tanpa SEC di atrium kiri dan kelompok dengan SEC di atrium kiri. Insidensi terjadinya penyakit serebrovaskular dan penyakit arteri perifer sebelumnya sedikit lebih tinggi pada kelompok dengan SEC di atrium kiri dibanding tanpa SEC namun perbedaannya tidak bermakna (masing-masing $p=0,5$ dan $p=0,248)$.

Data dasar mengenai irama jantung pada rekaman EKG dari subyek penelitian menunjukkan ada perbedaan bermakna, didapatkan $76,9 \%$ pasien tanpa irama FA dalam kelompok tanpa SEC di atrium kiri dan 96,2\% pasien dengan irama FA dalam kelompok dengan SEC, nilai $p=0,004$. Begitupun hasil laboratorium darah untuk pemeriksaan INR didapatkan ada perbedaan bermakna di antara kedua kelompok (nilai $p=0,007$ ). Namun, dari data penggunaan warfarin di antara kedua kelompok menunjukkan tidak ada perbedaan yang bermakna (nilai $p=0,185$ ). Kedua kelompok juga tidak mempunyai perbedaan bermakna dalam hasil laboratorium darah untuk 
Tabel 1. Karakteristik data dasar subyek penelitian

\begin{tabular}{|c|c|c|c|}
\hline & \multicolumn{2}{|c|}{ SEC di atrium kiri } & \multirow[b]{2}{*}{ Nilai $p$} \\
\hline & $\begin{array}{l}\text { Tidak ada } \\
(\mathrm{n}=52)\end{array}$ & $\begin{array}{c}\text { Ada } \\
(\mathrm{n}=52)\end{array}$ & \\
\hline Umur (tahun) & $40,25 \pm 10,63$ & $40,15 \pm 9,72$ & 0,962 \\
\hline \multicolumn{4}{|l|}{ Jenis kelamin } \\
\hline - Perempuan & $37(71,2 \%)$ & $38(73,1 \%)$ & 0,491 \\
\hline - Laki-laki & $15(28,8 \%)$ & $14(26,9 \%)$ & \\
\hline Hipertensi & $3(5,8 \%)$ & $2(3,8 \%)$ & 0,5 \\
\hline Penyakit serebrovaskuler & $2(3,8 \%)$ & $3(5,8 \%)$ & 0,5 \\
\hline Penyakit arteri perifer & 0 & $2(3,8 \%)$ & 0,248 \\
\hline Fibrilasi atrium & $40(76,9 \%)$ & $50(96,2 \%)$ & 0,004 \\
\hline Konsumsi obat warfarin & $35(67,3 \%)$ & $41(78,8 \%)$ & 0,185 \\
\hline INR & $1,26(0,89-9,19)$ & $1,4(0,78-5,58)$ & 0,007 \\
\hline Kreatinin (mg/dl) & $0,82(0,51-2,63)$ & $0,78(0,38-2,22)$ & 0,198 \\
\hline
\end{tabular}

pemeriksaan kreatinin, nilai $p=0,198$ (Tabel 1).

Hasil laboratorium darah untuk parameter pemeriksaan darah lengkap menunjukan ada perbedaan sangat bermakna untuk beberapa parameter pemeriksaan darah lengkap di antara ke dua kelompok yaitu parameter hemoglobin, hematokrit, limfosit dan rasio $\mathrm{N} / \mathrm{L}$, dengan nilai $p$ yang sama yaitu $p<0,001$. Lalu parameter distribusi sel darah merah (RDW) dan eosinofil yaitu masing-masing $p=0,033$ dan $p=0,012$. Untuk distribusi sel darah putih, tidak ditemukan perbedaan yang bermakna pada parameter neutrofil, monosit dan basofil di antara ke dua kelompok (masing-masing nilai $p=0,078, p=0,092$, dan $p=$ 0,053). Namun, untuk nilai limfosit didapatkan perbedaan yang sangat bermakna di antara ke dua kelompok dengan nilai $p<0,001$ yaitu nilai limfosit pada kelompok SEC di atrium kiri $(1,21 \pm 0,48)$ lebih kecil dibandingkan nilai limfosit pada kelompok tanpa SEC di atrium kiri $(2,21 \pm 6,78)$. Begitu pula nilai eosinofil $(0,29 \pm 0,31)$ pada kelompok dengan SEC di atrium kiri lebih kecil dibandingkan nilai eosinofil $(0,39 \pm 0,32)$ pada kelompok tanpa SEC di atrium kiri, nilai $p=0,012$. Setelah dilakukan perhitungan rasio neutrofil/limfosit tampak bahwa ada perbedaan yang sangat bermakna di antara ke dua kelompok yaitu rasio N/L pada kelompok dengan SEC di atrium kiri lebih besar dibandingkan kelompok tanpa SEC di atrium kiri (masing-masing yaitu 5,41 $\pm 4,83$ dan $2,3 \pm 0,91$ )

Tabel 2. Parameter pemeriksaan darah lengkap

\begin{tabular}{lccc}
\hline & \multicolumn{2}{c}{ SEC di atrium kiri } & Nilai $p$ \\
\cline { 2 - 3 } & $\begin{array}{c}\text { Tidak ada } \\
(\mathrm{n}=52)\end{array}$ & $\begin{array}{c}\text { Ada } \\
(\mathrm{n}=52)\end{array}$ & $<0,001$ \\
\hline Hemoglobin $(\mathrm{g} / \mathrm{dL})$ & $14,04 \pm 1,41$ & $12,6 \pm 1,63$ & $<0,001$ \\
Hematokrit $(\%)$ & $41,65(34,5-52,4)$ & $39(10,2-47,9)$ & 0,37 \\
Lekosit $\left(10^{3} / \mathrm{mm}^{3}\right)$ & $8,06 \pm 1,54$ & $7,37 \pm 1,76$ & 0,165 \\
Platelet $\left(10^{3} \mu \mathrm{L}\right)$ & $234,59 \pm 87,85$ & $216,42 \pm 80,84$ & 0,033 \\
RDW $(\%)$ & $13,8(12,2-22,4)$ & $15,15(12,1-22)$ & 0,134 \\
MPV $(\mathrm{fL})$ & $10,16 \pm 0,91$ & $9,89 \pm 0,99$ & 0,053 \\
Plateletcrit $(\%)$ & $0,23(0,11-0,73)$ & $0,2(0,09-0,37)$ & 0,07 \\
PDW $(\mathrm{fL})$ & $11,3(8,2-16)$ & $10(7,2-16,1)$ & 0,078 \\
Netrofil $\left(10^{3} / \mu \mathrm{L}\right)$ & $4,69 \pm 1,23$ & $5,19 \pm 1,55$ & $<0,001$ \\
Limfosit $\left(10^{3} / \mu \mathrm{L}\right)$ & $2,21 \pm 6,78$ & $1,21 \pm 0,48$ & 0,092 \\
Monosit $\left(10^{3} / \mu \mathrm{L}\right)$ & $0,70 \pm 1,78$ & $0,64 \pm 0,22$ & 0,012 \\
Eosinofil $\left(10^{3} / \mu \mathrm{L}\right)$ & $0,39 \pm 0,32$ & $0,29 \pm 0,31$ & 0,053 \\
Basofil $\left(10^{3} / \mu \mathrm{L}\right)$ & $0,04(0,01-0,29)$ & $0,03(0-0,19)$ & $<0,001$ \\
Rasio Netrofil/Limfosit & $2,30 \pm 0,91$ & $5,41 \pm 4,83$ & \\
\hline
\end{tabular}


dengan nilai $p<0,001$ (Tabel 2).

Dari parameter ekokardiografi didapatkan bahwa fraksi ejeksi ventrikel kiri dan fraksi pemendekan dari subyek penelitian tidak berbeda bermakna antara dua kelompok. Fungsi regional ventrikel kanan yang diwakili oleh TAPSE, diameter basal ventrikel kanan dan tekanan sistolik arteri pulmonal juga memiliki perbedaan tidak bermakna antara kedua kelompok. Sedangkan parameter ekokardiografi lain memiliki perbedaan bermakna di antara kedua kelompok yaitu diameter atrium kiri, area katup mitral dan regurgitasi mitral. Diameter atrium kiri pada kelompok SEC $(6,09 \pm 2)$ memiliki diameter lebih besar dibanding kelompok tanpa SEC $(5,27 \pm 1)$ dengan nilai $p=0,02$. Sebaliknya, parameter luas area katup mitral (MVA) yang diukur dengan metode planimetri pada kelompok dengan SEC di atrium kiri mempunyai luas area lebih kecil dibandingkan kelompok tanpa SEC di atrium kiri yaitu masing-masing $0,62 \pm 0,20$ dan $0,90 \pm 0,38$ dengan nilai $p<0,001$. Sedangkan parameter regurgitasi mitral yaitu regurgitasi mitral tidak signifikan (tidak ada regurgitasi sampai derajat ringan) lebih sering berada di kelompok dengan SEC di atrium kiri (76,9\%) dibandingkan kelompok tanpa SEC di atrium kiri $(51,9 \%)$ dengan nilai $p=0,008$ (Tabel 3).

Dari kedua kelompok, beberapa variabel yang kemungkinan berpengaruh terhadap SEC adalah variabel-variabel yang mempunyai perbedaan bermakna di antara dua kelompok. Dengan demikian, beberapa variabel yang berpengaruh terhadap SEC

Tabel 3. Parameter ekokardiografi

\begin{tabular}{|c|c|c|c|}
\hline & \multicolumn{2}{|c|}{ SEC di atrium kiri } & \multirow[t]{2}{*}{ Nilai $p$} \\
\hline & $\begin{array}{c}\text { Tidak ada } \\
(\mathrm{n}=52)\end{array}$ & $\begin{array}{c}\text { Ada } \\
(\mathrm{n}=52)\end{array}$ & \\
\hline Diameter atrium kiri & $5(3,1-8,3)$ & $6,1(4,3-14,3)$ & 0,02 \\
\hline Ejeksi fraksi ventrikel kiri (\%) & $55(35-77)$ & $56(28-86)$ & 0,912 \\
\hline Fraksi pemendekan (\%) & $28(16-43)$ & $29,5(16-56)$ & 0,909 \\
\hline Area katup mitral $\left(\mathrm{cm}^{2}\right)$ & $0,8(0,4-1,8)$ & $0,6(0,2-1,4)$ & $<0,001$ \\
\hline Tekanan arteri pulmonal sistolik $(\mathrm{mmHg})$ & $59,48 \pm 23,81$ & $64,46 \pm 24,63$ & 0,297 \\
\hline Diameter basal ventrikel kanan $(\mathrm{cm})$ & $4,6(2,7-7,4)$ & $4,8(2,5-6,5)$ & 0,472 \\
\hline TAPSE $(\mathrm{cm})$ & $1,68 \pm 0,38$ & $1,56 \pm 0,39$ & 0,1 \\
\hline Regurgitasi mitral & & & 0,008 \\
\hline - tidak signifikan & $27(51,9 \%)$ & $40(76,9 \%)$ & \\
\hline - signifikan & $25(48,1 \%)$ & $12(23,1 \%)$ & \\
\hline
\end{tabular}

Tabel 4. Beberapa variabel yang berpengaruh terhadap SEC pada uji bivariat.

\begin{tabular}{lccc}
\hline & \multicolumn{3}{c}{ Analisis Bivariat } \\
\hline Fibrilasi atrium & RO & IK 95\% & Nilai p \\
Hemoglobin $>12 \mathrm{~g} \%$ & 7,500 & $1,586-35,464$ & 0.004 \\
Hematokrit $>42 \%$ & 0,076 & $0,016-0,347$ & $<0.001$ \\
RDW $\geq 15 \%$ & 0,212 & $0,084-0,538$ & $<0.001$ \\
Plateletcrit $>0,2 \%$ & 3,167 & $1,394-7,191$ & 0.005 \\
Rasio Netrofil/Limfosit $>3,2$ & 0,347 & $0,154-0,782$ & 0.01 \\
Diameter atrium kiri $>4,5 \mathrm{~cm}$ & 17,640 & $6,652-46,781$ & $<0.001$ \\
Area katup mitral $\leq 0,9 \mathrm{~cm}$ & 2,522 & $0,809-7,863$ & 0.103 \\
Regurgitasi mitral tidak signifikan & 12,143 & $2,636-55,938$ & $<0.001$ \\
TAPSE $\leq 1,6 \mathrm{~cm}$ & 0,324 & $0,139-0,753$ & 0.008 \\
Tidak minum obat warfarin & 2,368 & $1,077-5,209$ & 0,031 \\
INR $<2$ & 0,552 & $0,229-1,335$ & 0,185 \\
\hline
\end{tabular}

nilai p signifikan jika $<0,05$ 
dianalisa menggunakan uji bivariat (Tabel 4).

Variabel-variabel yang mempunyai nilai $p \leq 0,1$ pada analisis bivariat diidentifikasi sebagai penandapenanda risiko yang potensial untuk kejadian SEC di atrium kiri dan dimasukkan ke dalam analisis logistik regresi multivariat dengan metode backward.

Dari hasil analisis multivariat (Tabel 5), diperoleh beberapa variabel yang dapat menjadi prediktor bebas terhadap SEC di atrium kiri yaitu fibrilasi atrium $(p=$ $0,003)$, RDW ( $p=0,018)$, rasio neutrofil/limfosit $(p<$ $0,001)$ dan luas area katup mitral $(p=0,015)$. Kekuatan hubungan dilihat dari nilai odds rasio (OR). Kekuatan hubungan dari terbesar ke yang terkecil adalah fibrilasi atrium $(\mathrm{OR}=51,31)$, rasio neutrofil/limfosit $(\mathrm{OR}=$ $21,641)$, luas area katup mitral $(\mathrm{OR}=14,423)$, dan evaluasi klinis melalui hasil catatan pemeriksaan klinis, rekaman EKG, hasil laboratorium dan rekaman di alat ekokardiografi. Sedangkan pemeriksaan fototoraks tidak dilakukan karena bacaan hasilnya tidak lengkap. Dari evaluasi tersebut, peneliti mendapatkan beberapa variabel yang berhubungan dengan kehadiran spontaneous echocardiographic contrast di atrium kiri.

Adanya SEC di atrium kiri telah dilaporkan menjadi prediktor bebas untuk risiko tromboemboli pada pasien-pasien dengan penyakit katup mitral rematik. Dalam suatu literatur sebelumnya, telah dilaporkan tentang faktor-faktor prediktor untuk berkembangnya SEC pada pasien stenosis mitral. Variabel-variabel yang termasuk yaitu area katup mitral, diameter dan luas atrium kiri, fibrilasi atrium,

Tabel 5. Hasil analisis multivariat regresi logistik

\begin{tabular}{lcccc}
\hline & Koefisien & Nilaip & OR & IK 95\% \\
\hline Fibrilasi atrium & 3,938 & 0,003 & 51,311 & $3,723-707,100$ \\
Hemoglobin $>12 \mathrm{~g} \%$ & $-2,613$ & 0,077 & 0,073 & $0,004-1,328$ \\
Hematokrit $>42 \%$ & $-1,291$ & 0,075 & 0,275 & $0,067-1,137$ \\
RDW $\geq 15 \%$ & 1,748 & 0,018 & 5,743 & $1,349-24,445$ \\
Rasio Netrofil/Limfosit $>3,2$ & 3,075 & 0,000 & 21,641 & $5,174-90,528$ \\
Area katup mitral $\leq 0,9 \mathrm{~cm}^{2}$ & 2,669 & 0,015 & 14,423 & $1,665-124,908$ \\
Konstanta & $-7,838$ & 0,000 & 0,000 & \\
\hline
\end{tabular}

nilai p signifikan jika $<0,05$

RDW $(\mathrm{OR}=5,743)$.

Adanya hubungan yang sangat bermakna antara rasio neutrofil/limfosit dan SEC di atrium kiri pada hasil analisis multivariat regresi logistik, maka perlu dicari nilai titik potong (cut off) dari rasio neutrofil/ limfosit yang berpengaruh terhadap kejadian SEC di atrium kiri pada pasien stenosis mitral rematik. Dengan menggunakan kurva koordinat ROC, didapatkan nilai titik potong untuk rasio N/L adalah 3,217 dengan nilai $\mathrm{AUC}=0,883(p<0,001)$, yang artinya nilai titik potong rasio $\mathrm{N} / \mathrm{L}$ ini memiliki kekuatan diagnostik yang kuat $(>80 \%-90 \%)$. Dari hasil perhitungan uji diagnostik untuk rasio neutrofil/limfosit dengan titik potong $>3,2$ didapatkan nilai sensitivitas, spesifisitas, nilai prediksi positif dan nilai prediksi negatif yang sama yaitu masing-masing $81 \%$.

\section{Pembahasan}

Semua pasien stenosis mitral rematik yang masuk kriteria inklusi dalam penelitian ini, dilakukan derajat severitas stenosis mitral dan faktor-faktor hematologi seperti hematokrit, RDW, dan jenis sel darah putih..$^{3,11-14}$

Populasi pasien dalam penelitian ini lebih banyak berusia muda (usia produktif) dengan jenis kelamin yang paling banyak adalah perempuan, lebih dua pertiga dari keseluruhan sampel. Namun, hasil statistik menunjukkan tidak ada perbedaan yang bermakna pada variabel usia dan jenis kelamin antara kedua kelompok. Hasil ini mirip dengan penelitian yang dilakukan di negara Turki baru-baru ini dan beberapa penelitian lainnya. ${ }^{6,15}$ Dalam penelitian-penelitian yang mereka lakukan, didapatkan tidak ada perbedaan yang bermakna secara statistik untuk usia di antara kelompok tanpa SEC dan kelompok dengan SEC. Hanya saja, usia tua cenderung lebih banyak berada di kelompok dengan SEC pada penelitian sebelumnya. Sedangkan dalam penelitian ini hampir tidak ada perbedaan usia antara kelompok tanpa SEC (usia ratarata 40,25 tahun) dan kelompok dengan SEC (usia rata-rata 40,15 tahun). Hal ini mungkin disebabkan karena cara perekrutan sampel yang hanya ditujukan 
pada stenosis mitral dengan penyebab rematik sedangkan penelitian sebelumnya dilakukan pada stenosis mitral dengan semua penyebab. Di literatur telah disebutkan bahwa penyebab stenosis mitral selain rematik juga disebabkan penyakit degeneratif sehingga bila dimasukkan dalam populasi sampel maka usia tua cenderung lebih banyak di kelompok dengan SEC dan hal ini sesuai dengan patofisiologinya.

Penelitian-penelitian sebelumnya telah mengamati bahwa fibrilasi atrium berhubungan dengan SEC di atrium kiri pada pasien stenosis mitral.3,16 Dalam penelitian ini, fibrilasi atrium lebih banyak pada kelompok dengan SEC (96,2\% lawan 76,9\%, nilai $p=$ 0,004). Pada hasil analisis multivariat regresi logistik, parameter fibrilasi atrium juga masuk menjadi salah satu prediktor bebas untuk SEC di atrium kiri $(\mathrm{OR}=$ $51,311$, nilai $p=0,003)$. Sedang pada penelitian yang dilakukan oleh Sanaa dkk, fibrilasi atrium juga lebih banyak pada kelompok dengan SEC (60\% lawan $31,7 \%$, nilai $p<0,001)$ tapi pada analisis multivariat regresi, parameter fibrilasi atrium memiliki hubungan tidak bermakna $(\mathrm{OR}=0,6$, nilai $p=0,294) \cdot{ }^{17}$

Dijelaskan dalam literatur sebelumnya bahwa laju dan irama atrial yang tidak normal berkontribusi terhadap trombogenesis dengan cara: 1) laju atrial cepat dikaitkan dengan peningkatan aktivasi platelet dan generasi trombin; 2) fibrilasi atrium, meskipun juga menunjukkan perubahan aktivasi platelet dan generasi trombin, selain itu menyebabkan disfungsi endotelial dan aktivasi kaskade inflamasi, dan 3) yang menarik, faktor-faktor ini terjadi jauh lebih besar pada atrium kiri dibandingkan dengan sirkulasi perifer. $^{12}$

Dari parameter laboratorium didapatkan beberapa parameter yang bisa menjadi prediktor bebas terhadap SEC di atrium kiri seperti hemoglobin, hematokrit, RDW, plateletcrit dan rasio neutrofil/limfosit. Namun setelah dilakukan analisis multivariat regresi logistik, didapatkan dua parameter yang bermakna terhadap SEC di atrium kiri adalah rasio N/L $(p<0,001)$ dan RDW ( $p=0,018)$. Rasio neutrofil/limfosit $>3,2$ yang diukur dalam jarak waktu $\leq 2$ hari sebelum atau sesudah pemeriksaan ekokardiografi mempunyai sensitivitas, spesifisitas, nilai prediksi positif dan nilai prediksi negatif yang sama yaitu masing-masing $81 \%$ untuk memprediksi SEC di atrium kiri pada pasien stenosis mitral rematik. Hasil ini hampir mendekati sama dengan hasil penelitian Mehmet dkk yang dimuat dalam American Journal Cardiology 2012 yaitu nilai rasio $\mathrm{N} / \mathrm{L}>3,1$ dengan sensitivitas $80 \%$ dan spesifisitas $72 \%$ untuk memprediksi SEC pada pasien stenosis mitral. ${ }^{18}$ Dimana penelitian mereka menggunakan ekokardiografi transesofageal (TEE) untuk melihat kehadiran SEC sedangkan penelitian ini hanya menggunakan ekokardiografi transtorakal (TTE). Telah disebutkan bahwa sensitivitas dan spesifisitas TEE lebih superior dibanding TTE dalam mengevaluasi SEC di ruang jantung terutama SEC yang sering berlokasi di aurikel atrium kiri, dimana TEE menjadi pilihan utama (gold standard). ${ }^{19}$

Beberapa literatur menjelaskan bahwa inflamasi berperan penting dalam proses pembentukan SEC. Rasio neutrofil/limfosit merupakan salah satu indikator inflamasi sistemik pada beberapa penelitian epidemiologi. Pada kasus infark miokard akut, terjadi limfositopenia dan granulositosis yang menyebabkan peningkatan rasio $\mathrm{N} / \mathrm{L}$, keadaan ini akan kembali normal pada infak miokard tanpa komplikasi. Berbeda halnya dengan stenosis mitral dengan penyebab rematik dimana proses inflamasi penyakitnya tetap berlangsung terus menerus walaupun tidak disertai gejala. ${ }^{9,20}$

Parameter laboratorium lain yang didapatkan berpengaruh terhadap SEC di atrium kiri adalah RDW. Hasil analisis multivariat regresi logistik menunjukan $\mathrm{RDW} \geq 15 \% \quad(\mathrm{OR}=5,743$, nilai $\mathrm{IK} 95 \%$ antara $1,349-24,445$, nilai $p=0,018$ ) bisa menjadi prediktor SEC di atrium kiri pada pasien stenosis mitral rematik. Penelitian Rui yang dimuat dalam American Journal Cardiovascular 2013 menunjukkan bahwa RDW $\geq 15 \%$ menjadi prediktor untuk stasis atrium kiri pada pasien fibrilasi atrium non-valvular. Hal ini dikaitkan dengan adanya hipotesis mengenai komposisi dari SEC yaitu berasal dari agregasi selsel darah merah yang berinteraksi dengan protein plasma. ${ }^{21,22}$

Pada parameter ekokardiografi didapatkan beberapa parameter yang berhubungan bermakna dengan SEC di atrium kiri pada pasien stenosis mitral rematik dari hasil analisis bivariat yaitu diameter atrium kiri $<4,5$ $\mathrm{cm}$, area katup mitral $\leq 0,9 \mathrm{~cm}^{2}$, regurgitasi mitral tidak signifikan (tidak ada regurgitasi sampai derajat ringan) dan TAPSE $\leq 1,6 \mathrm{~cm}$. Semua variabel ini dimasukkan ke dalam analisis multivariat regresi logistik, didapatkan hasil ternyata hanya area katup mitral yang menjadi prediktor bebas untuk SEC di atrium kiri pada pasien stenosis mitral rematik $(p=0,015)$. Beberapa penelitian telah menunjukkan bahwa prevalensi SEC meningkat seiring dengan penurunan area katup mitral. ${ }^{15,17}$ Penelitian Beppu dkk, mereka membagi klasifikasi kasus menjadi tiga kategori berdasarkan rata-rata area katup 
mitral dan SEC yaitu bila MVA $0,7 \mathrm{~cm}^{2}$ berhubungan dengan SEC berat, MVA 1, $1 \mathrm{~cm}^{2}$ berhubungan dengan SEC ringan, dan MVA $1,5 \mathrm{~cm}^{2}$ tidak berkaitan dengan SEC. Sedangkan dalam penelitian ini, ukuran area katup mitral yang beresiko tinggi untuk kejadian SEC pada pasien stenosis mitral rematik adalah $\leq 0,9 \mathrm{~cm}^{2}$. Data ini bisa dikaitkan dengan fakta bahwa penderita yang mengalami stenosis mitral berat tanpa adanya regurgitasi mitral berisiko tinggi untuk terbentuk SEC. Hal ini sesuai dengan hipotesis yang menyatakan bahwa adanya regurgitasi mitral yang signifikan (derajat sedang sampai berat) dan area katup mitral yang besar akan mencegah terjadinya stasis darah di ruang atrium kiri. ${ }^{3,23}$

Dalam penelitian ini, semua pasien menjalani pemeriksaan ekokardiografi transtorakal (TTE) tanpa diikuti oleh pemeriksaan ekokardiografi transesofagel (TEE). Berbeda dengan penelitian di luar negeri dimana TEE telah rutin dipakai untuk melihat kehadiran SEC. Pada penelitian Mehmet dkk, menemukan trombus sekitar 20\% dan SEC sekitar 38\% di atrium kiri dari keseluruhan pasien yang diteliti dengan TEE tapi tidak terlihat pada TTE. ${ }^{24}$ Penelitian yang dilakukan oleh Ying-Tsung Chen di China pada tahun 1989, menunjukkan hasil bahwa TTE hanya bisa mendeteksi SEC di atrium kiri 1 dari 139 pasien stenosis mitral sedangkan TEE mampu mendeteksi SEC di atrium kiri sekitar 44,6\% dari jumlah tersebut. Kesimpulannya adalah ekokardiografi transesofageal lebih sensitif untuk mendeteksi SEC di atrium kiri dibandingkan dengan ekokardiografi transtorakal. ${ }^{25}$ Untuk penelitian selanjutnya, peneliti menyarankan perlu mempertimbangkan penggunaan ekokardiografi transesofageal bila pada pasien stenosis mitral rematik didapatkan irama jantung berupa fibrilasi atrium, area katup mitral $<1 \mathrm{~cm}^{2}$ dan rasio neutrofil/limfosit $>3,2$ namun belum jelas terlihat adanya SEC di atrium kiri dengan pemeriksaan TTE. Ekokardiografi transesofageal digunakan terutama untuk melihat kehadiran SEC atau trombus di ruang aurikel atrium kiri yang sering menjadi tempat bersarang SEC yang sulit dijangkau dengan alat ekokardiografi transtorakal.

\section{Kesimpulan}

Kami menyimpulkan pada penelitian ini bahwa fibrilasi atrium, rasio neutrofil/limfosit, RDW dan area katup mitral dapat menjadi prediktor kejadian SEC di atrium kiri pada pasien stenosis mitral rematik. Dari penelitian ini juga diperoleh nilai rasio neutrofil/limfosit > 3,2 memiliki angka sensitivitas, spesifisitas, nilai prediksi positif dan nilai prediksi negatif yang sama yaitu masing-masing $81 \%$ untuk memprediksi SEC di atrium kiri pada pasien stenosis mitral rematik.

\section{Batasan Penelitian}

1. Penelitian ini hanya observasi di satu pusat pendidikan dengan jumlah sampel yang sedikit. Namun, populasi dalam penelitian ini diusahakan homogen melalui metode pengambilan sampling dari pasien stenosis mitral rematik sehingga bisa mencerminkan sampel yang besar.

2. Penelitian ini menggunakan ekokardiografi transtorakal untuk melihat kehadiran SEC di atrium kiri, sehingga adanya SEC yang sering berlokasi di aurikel atrium kiri tidak terlihat jelas.

\section{Ucapan Terima Kasih}

Peneliti mengucapkan banyak terima kasih kepada Dr. dr. Zulfikri Mukhtar, SpJP(K), dr. Nizam Zikri Akbar, $\operatorname{SpJP}(K)$, dr. Andre Pasha Ketaren, $\operatorname{SpJP}(K)$ dan dr. Anggia Chairudin Lubis, M.Ked (Card), SpJP atas segala saran dan bimbingan dalam penelitian ini.

\section{Daftar Singkatan}

\author{
SEC: Spontaneous Echocardiographic Contrast \\ FA: Fibrilasi Atrium \\ IK: Interval Kepercayaan \\ MPV: Mean Platelet Volume \\ MVA: Mitral Valve Area (area katup mitral) \\ OR: Odds Rasio \\ PDW: Platelet Distribution Width \\ RDW: Red Cell Distribution Width \\ Rasio N/L: Rasio Neutrofil/Limfosit \\ TAPSE: Tricuspid Annular Plane Systolic Excursion \\ TEE: Transesofageal Echocardiography \\ TTE: Transthoracal Echocardiography
}

\section{Persetujuan Etik}

Penelitian ini telah disetujui oleh Komisi Etik Rumah Sakit Umum Pusat Haji Adam Malik, Medan, 


\section{Indonesia}

\section{Persetujuan untuk Publikasi}

Semua pihak telah menyetujui publikasi naskah ini.

\section{Konflik Kepentingan}

Tidak ada konflik kepentingan dalam penelitian ini. Pendanaan

Pendanaan untuk penelitian ini berasal dari dana pribadi.

\section{Daftar Pustaka}

1. Davutoglu V, Celik A, Aksoy M. "Contribution of selected serum inflammatory mediators to the progression of chronic rheumatin valve disease, subsequent valve calcification and NYHA functional class." J Heart Valve Dis 14 (2005): 251-256.

2. Otto CM., Bonow RO. "Valvular Heart Disease." Chap. 63 in Braunwald's Heat Disease: A Textbook of Cardiovascular Medicine, by Eugene Braunwald, 1469. 2015.

3. Beppu S, Park YD, Sakakibara H, et al. "Smoke-like echo in the left atrial cavity in mitral valve disease: its features and significance." J Am Call Cardiol, 1985: 744-749.

4. Ozkan M, Kaymaz C, Kirma C, Civelek A, Cenal AR, Yakut $\mathrm{C}$, et al. "Predictors of the left atrial clot and spontaneous echo contrast in rheumatic valve diseae before and after mitral valve replacement." Am J Cardiol 82 (1998): 1066-1070.

5. Beppu S. "Hypercoagulability in the left atrium: Part I: Echocardiography." J Heart Valve Disease, 1993: 18-24.

6. Bayar N, Erkal Z, Kucukseymen S, Guven R, Arslan S. "Relationship between spontaneous echo contrast and hematological markers in patients with rheumatic mitral stenosis." International Journal of the Cardiovascular Academy, 2016: 127-130.

7. Shen XH, Chen Q, Shi Y, Li HW. "Association of neutrophil/ lymphocyte ratio with long-term mortality after ST elevation myocardial infarction treated with primary percutaneous coronary interventions." Chin Med J. 123 (2010): 3438-3443.

8. Kaya H, Ertas F, Islamoglu Y, et al. "Association between neutrophil to lymphocyte ratio and severity of coronaryartery disease." Clin Appl Thromb Hemost 20 (2014): 50-54.

9. Ozturk D, Ertuk M, Celik O, Ozyilmaz S, Akturk F, Cakmak HA, et al. "The role of the neutrophil/lymphocyte ratio in patients with rheumatic mitral stenosis as an indicator of spontaneous echocardiographic contrast.” Kardiol Pol 72 (2014): 969-976.

10. Baysal E, Burak C, Cay S, Aksu T, Altintas B, Yaylak B, et al.
"The neutrophil to lymphocyte ratio is associated with severity of rheumatic mitral valve stenosis." Journal of Blood Medicine, 2015: 151-156.

11. Daniel WG, Nellessen U, Schroder E. "Left atrial spontaneous echo contrast in mitral valve disease: an indicator for an increased thromboembolic risk." J Am Coll Cardiol, 1988: 1204-1211.

12. Lim HS, Willoughby SR, Schultz C, Gan C, Alasady M, Lau $\mathrm{DH}$, et al. "Effect of atrial fibrillation on atrial thrombogenesis in humans: Impact of rate and rhytm." J Am Coll Cardiol, 2013: 852-860.

13. Providencia R, Ferreira MJ, Goncalves L, Faustino A, Paiva L, Fernandes A, et al. "Mean courpuscular volume and red cell distribution width as predictors of left atrial stasis in patients with non-valvular atrial fibrillation." Am J Cardiovasc Dis 3, no. 2 (2013): 91-102.

14. Islam MJ, Majumder AAS, Ali MA, Dutta B, Karmoker KK, Imrana F, et al. "Association of Left Atrial Spontaneous Echocardiographic Contrast with Inflammatory Markers in Mitral Stenosis Patients." Cardiovasc J 7 (2014): 24-30.

15. Black IW., Hopkins AP, Lee LCL, Walsh WF. "Left atrial spontaneous echo contrast: a clinical and echocardiographic analysis." J Am Coll Cardiol, 1991: 398-404.

16. Goswani KC, Yadav R, Rao MB, Bahl VK, Talwar KK, Manchanda SC. "Clinical and echocardiographic predictors of left atrial clot and spontaneous echo contrast in patients with severe rheumatic mitral stenosis: a prospective study in 200 patients by transesophageal echocardiography." Int J Cardiol 73 (2000): 273-279.

17. Drissi S, Sabor H, Ounsy A, Mouine N, Sabry M, Benyass A, et al. "Predictive factors of left atrial spontaneous echo contrast in patients with rheumatic mitral valve stenosis: a retrospective study of 159 patients." International Archives of Medicine 7 (2014): 32.

18. Kaya MG, Akpek M, Elcik D. "Relation of left atrial spontaneous echocardographic contrast in patients with mitral stenosis to inflammatory markers." Am J Cardiol, 2012: 851-855.

19. Saric M, Armour AC, Arnaout MS, Chaudhry FA, Grimm RA, Kronzon I, et al. "Guidelines for the Use of Echocardiography in the Evaluation of a Cardiac Source of Embolism." J Am Soc Echocardiography 29 (2016): 1-42.

20. Akboga MK, Akyel A, Sahinarslan A, Yayla A, Alsancak Y, Gokalp G, et al. "Neutrophil-to-lymphocyte ratio is increased in patients with rheumatic mitral valve stenosis?" Anatol J Cardiol, 2015: 380384.

21. Mahony C., Ferguson J, Fischer PL. "Red cell agregation and the echogenicity of whole blood." Ultrasound Med Biol 18 (1992): 579-586.

22. DeFilippis AP, Law K, Curtin S, Eckman JR. "Blood is thicker than water: the management of hyperviscosity in adults with cyanotic heart disease." Cardiol Rev 15 (2007): 31-34. 


\section{Indonesian Journal Of Cardiology}

23. Tsai LM., Chen JH, Fang CJ, Lin LJ, Kwan CM. "Clinical implications of left atrial spontaneous echo contrast in nonrheumatic atrial fibrillation.” Am J Cardiol, 1992: 327-331.

24. Bilge M., Guler N, Eryonucu B, Asker M. "Frequency of left atrial thrombus and spontaneous echocardiographic contrast in acute myocardial infarction." Am J Cardiol, 1999: 847-849.

25. Chen YT, Kan MN, Chen JS, Lin WW, Hwang DS, Chang M, et al. "Contributing factors to formation of left atrial spontaneous echo contrast in mitral valvular disease." J Ultrasound Med 9 (1990): 151. 